\title{
Mole per Mole
}

National Cancer Institute

\section{Source}

National Cancer Institute. Mole per Mole. NCI Thesaurus. Code C70455.

A unit of fraction expressed as the ratio of the amount of substance of solute in moles to the amount of substance of the mixture in moles. 